\title{
Special Education Complaint Resolution: Ohio
}

\author{
RUTH COLKER ${ }^{*}$
}

Under the Individuals with Disabilities Education Act ("IDEA"), ${ }^{1}$ students and their parents have a number of mechanisms to assert that a school district is not complying with the IDEA with respect to a student's education. The most widely discussed mechanism is filing a due process complaint with the student's school of residence requesting an impartial due process hearing. ${ }^{2}$ Students and their parents must exhaust this administrative process before pursuing their rights under the IDEA in state or federal court. ${ }^{3}$ Thus, that process is an important aspect of the enforcement of the IDEA. I have examined that process in previous work, concluding that it is a cumbersome process to protect the rights of students, especially when a lawyer does not represent the student. ${ }^{4}$ In the various states I have examined, the success rate for students is lower than the success rate for school districts when they file for due process. 5

The IDEA, however, also includes another type of dispute resolution process: filing a state administrative complaint. Each state must have a procedure to allow an individual or organization to file a signed written

* Distinguished University Professor \& Heck-Faust Memorial Chair in Constitutional Law, Moritz College of the Law, the Ohio State University. I would like to thank Moritz librarian Stephanie Ziegler for helping me locate the decisions I discuss in this article. I would like to thank the Ohio State Journal on Dispute Resolution, especially Nick Uzl and Carolyn Cole, for making it possible for me to present this work at a stimulating symposium. Finally, I would like to thank Michael Gregory for his helpful comments on an earlier draft.

120 U.S.C. $\S \S 1400-1482$ (2012).

2 See 20 U.S.C. $\S 1415(\mathrm{f})(2012)$.

3 See 34 C.F.R. $\$ 300.516(2014)$

4 See Ruth Colker, Disabled Education: A Critical analysis of the INDIVIDUALS WITH DISABILITIES EDUCATION ACT (2013).

${ }^{5}$ In Ohio, I found that students prevailed in 18 of 55 cases $(32.7 \%)$ decided by firstlevel hearing officers from 2002-2006, Id. at 149. In Florida, I found that students prevailed in 5 of 33 cases (15.1\%) from 2009-2011. Id at 160. In New Jersey, I found that students prevailed in 2 of 37 cases decided on a nonemergency basis $(5.4 \%)$ from 2009-2011. Id. at 172. In California, I found that students prevailed in 35 of 101 cases (34.6\%) from 2010-2011. Id. at 187. In the District of Columbia, I found that students prevailed in 57 of 100 cases (57\%) from 2010-2011. Id. at 211 . I considered students to have prevailed if they attained relief on a significant issue in a case, even if they did not necessarily attain the relief they requested. Thus, it is possible, if not likely, that some of the students in these cases would suggest that they did not attain adequate relief. Thus, these statistics reflect an arguably inflated rate of student success. 
complaint $^{6}$ regarding an IDEA violation that occurred not more than one year prior to the date that the state receives the complaint. ${ }^{7}$ Although the complaint can involve issues involving a specific child, it need not do so. ${ }^{8}$ Within sixty days of receiving the complaint, unless certain exceptions are met, the state must complete an investigation that can include an on-site investigation. Although no hearing is held, the state may collect information to resolve the complaint. ${ }^{9}$ The complainant may submit information, either orally or in writing, about the allegations of the complaint. The school district is also provided with an opportunity to respond to the complaint.

The key difference between complaints filed under those provisions and due process hearings is that there is no opportunity to assess the credibility of witnesses. ${ }^{10}$ The kinds of issues resolved in a complaint are ones in which facts can usually be determined from a paper record. The remedies also differ somewhat. In the complaint resolution process, the state may order corrective action such as compensatory services or monetary reimbursement where it finds a failure to provide appropriate services. Additionally, the state may order future provision of services for all children with disabilities. ${ }^{11}$ Unlike the resolution of a due process hearing, the state is not likely to order remedies that require subjective determinations such as the provision of publicly-funded private education for an individual child in the future. By contrast, the state is likely to order training for school staff when systemic violations are found to exist. Such systemic remedies are unlikely as part of the resolution of a due process complaint. Despite the inability to assess

6 Ohio has a form that parents can use to file a complaint. See Complaint Form, OHIO DEP'T EDUC., (Aug. 2009), http://education.ohio.gov/getattachment/Topics/SpecialEducation/Mediation-Complaints-and-Due-Process/Complaint-Form-2009.pdf.aspx (last viewed on March 11, 2014). The form appears to be available only in English. Like the entire ODE website, it is also not in an accessible form to individuals with visual impairments.

734 C.F.R. $\$ 300.153$ (2014).

834 C.F.R. $\$ 300.153(\mathrm{~b})(4)$ (2014).

934 C.F.R. $\$ 300.152$ (2014).

${ }^{10}$ Another important difference is that a state complaint can only assert issues that occurred not more than one year prior to the date that the complaint is received. 34 C.F.R. $\S 300.153$ (c) (2014). By contrast, a due process complaint can allege a violation that occurred not more than two years before the date the parent knew or should have known about the alleged action that forms the basis of the due process complaint. 34 C.F.R. $\S$ 300.507(a)(1) (2014). Finally, another important difference between administrative complaints and due process complaints is that administrative complaints cannot be appealed to a federal or state court. But due process decisions can be appealed to state or federal court. See 34 C.F.R. $\S 300.516$ (2014) (rules for civil actions).

1134 C.F.R. $\$ 300.151$ (2014). 
issues that require weighing the credibility of expert witnesses, the state investigators in Ohio sometimes find that Individualized Education Programs are inadequate or inappropriate in the complaint resolution process. ${ }^{12}$

In this article, I will discuss the resolution of state complaints, as well as due process hearings in Ohio. For the purpose of this study, I read the results of eighty-one state complaints resolved by the state of Ohio between May 7 , 2012 and May 27, 2013. I found that students and their parents are more likely to obtain some relief when they brought state complaints as compared to when they pursued due process hearings. Further, I find that the degree of professionalism in the resolution of state complaints in Ohio is much higher than the resolution of due process hearings. This finding may be unique to Ohio because Ohio uses part-time employees to resolve due process complaints under a two-tier system of resolution. ${ }^{13}$ By contrast, in Ohio, fulltime staff resolves state complaints. Comparison with states like Pennsylvania, that have eliminated a two-tier hearing officer process and created full-time hearing officers, would be interesting to determine if that kind of change increases the professionalism of hearing officer decisions and creates more parity between the results under the state complaint and hearing officer processes.

In Part I, after offering a typical example of a complaint investigation, I will offer some quantitative and qualitative data on the resolutions of complaints in Ohio. I will discuss how the following issues often resulted in favorable outcomes for the student: (1) who should be in attendance at IEP meetings, (2) lack of parent communication/progress reports, (3) poor scheduling of IEP meetings, (4) inadequately written IEPs, (5) need for continuum of placements, (6) improper use of seclusion and restraint, (7) obligations of community schools, and (8) failing to conduct evaluations/ child find. By contrast, I will discuss in Part II, the relatively few hearing officer decisions rendered during this time frame and suggest that those

12 See infra Part I.

13 See State Bd. Educ. OHIO, Operating Standards for OHIO Educational Agencies Serving ChILdREN with Disabilities $\S 3301-51-05(\mathrm{~K})(10)(\mathrm{c})$ (2008) (specifying qualifications of hearing officers), available at http://education.ohio.gov/ getattachment/Topics/Special-Education/Students-with-Disabilities/OperationalStandards-and-Guidance/Operating-Standards-for-Ohio-Educational-Agencies-ServingChildren-with-Disabilities-2008.pdf.aspx. The school district pays the hearing officer. See OHIO DeP'T EduC., WhOSE IDEA Is ThIS?: A PARENT's GuIDE to THE INDIVIDUALS WITH DISABILITIES EDUCATION IMPROVEMENT ACT OF 200437 (2012), available at http://education.ohio.gov/getattachment/Topics/Special-Education/Students-withDisabilities/Physical-or-Mentally-Handicap/Whose-IDEA-Is-This-A-Parent-s-Guide-tothe-Individ/Whose-IDEA.pdf.aspx. 
results were often less satisfactory than the results achieved through the state complaint procedure. In Part III, I will conclude.

\section{COMPLAINT INVESTIGATIONS}

\section{A. Introduction}

To provide a sense of the difference between the complaint resolution process and the hearing officer due process resolution, it is helpful to consider a concrete example of a complaint investigation. The following example is used because it is representative of the complaints analyzed for this article.

On October 15, 2013, a parent filed a complaint with the Office for Exceptional Children involving two issues regarding her child's treatment in the Athens City School District. ${ }^{14}$ She complained that the school district unilaterally changed her son's aide from one-on-one to a shared aide, and also deprived him transportation so that he could attend a school field trip. Both issues involved the question of whether the school district was following the existing IEP. The parent was not seeking a revision of the IEP. Monica Drvota, a state employee, ${ }^{15}$ was assigned to investigate the complaint.

With respect to the first issue, the investigator read the IEP for this year and last year, interviewed the parent and the Special Education Director, and received written statements from the six attendants who provided services in the student's classroom. The basic facts were not in dispute. The student had been receiving the same one-on-one aide since the 2009-2010 school year. But, during the 2013 school year, the school district changed the aide from the man who had been the student's aide for several years to a woman who the student shared with another student in the classroom. The child has autism and the parent argued that the child was regressing with this change in personnel. The IEP, however, did not specify that a particular individual would be the aide. Further, the IEP stated that the student would receive "attendant services" but did not specify they would be one-on-one services.

14 See CP 0173-2013, Findings Letter, OHIO DeP'T EDUC. (Dec. 13, 2013), http://www.edresourcesohio.org/wp-content/uploads/2014/01/CP-0173-2013.pdf.

15 The state's website describes Drvota as Assistant Director, Procedural Safeguards, Office for Exceptional Children. See Office for Exceptional Children Contact Information, OHIO DEP'T EDUC., http://education.ohio.gov/Topics/SpecialEducation/Office-of-Exceptional-Children-Contact-Information (last visited on March 12, 2014). 
And, although the student was no longer assigned an aide to receive services on a one-on-one basis, the staffing of the classroom included eight teachers and nine students. In a due process complaint, the parent might have argued that the IEP need to be revised because the student was no longer making adequate progress, but the issue in a complaint investigation was merely whether the IEP, as written, was being followed. The oral assurances that the mother claimed she received that the prior male aide would continue to be the student's aide on a one-to-one basis were not memorialized as part of the IEP. Thus, in a complaint investigation, the school district was successful and no modifications were required with respect to the first issue.

With respect to the second issue, the investigator read the relevant IEP language, interviewed the parent, and interviewed the Special Education Director. The IEP stated that the student received transportation as a related service. Both the parent and school district agreed that the school district had refused to provide transportation for a school field trip. The school district took the position that the parent should provide transportation and the school district would reimburse the parent for transportation. However, that is not what the IEP said. Thus, the investigator found in favor of the parent/student on this issue. As relief, the school district was required to develop and sign a memorandum regarding the contents of two IEP regulations that were relevant to the resolution of this issue. As is typical in a complaint investigation, the relief was prospective. Had this matter been raised in a due process complaint, it is possible that the hearing officer would have ordered compensatory education for the lost opportunity to participate in a field trip, but such relief is unlikely in a complaint investigation. The decision in this matter was final. Neither the school district nor the parent had a right to appeal.

The findings letter was issued on December 13, 2013, two months after the parent filed the complaint. The resolution made the parent aware that there was a difference of opinion between herself and the school district with respect to how her son was progressing in the classroom. The mother took the position that the student was "sad, showing signs of depression, won't dress himself and does not want to go to school."16 The school staff took the position "that the student is happy and does not seem depressed."17 That kind of difference of opinion could not be resolved through the complaint investigation process. The transportation issue (which was likely of less importance to the parent), however, could be resolved in favor of the parent through the complaint investigation process, although no compensatory relief

${ }^{16}$ CP 0173-2013, supra note 14, at 2.

${ }^{17}$ Id. at 3. 
is likely to be ordered. ${ }^{18}$ The fact that the parent chose the complaint investigation process does not preclude the parent, in the future, from asking that the IEP be amended to provide more appropriate services for the student if evidence can demonstrate that he is regressing with the new aide.

This example is important to understanding the discussion that will follow. Although I will demonstrate that parents often attain some relief by using the complaint investigative process, one should also understand that there are limits to the kinds of relief that can be attained through this process. Broad relief, like extensive compensatory education and a nonpublic placement, are unlikely to be issued as a result of the complaint investigative process. Further, this process is not subject to judicial review. A decision is therefore final and immediately implemented. A parent who seeks a quick resolution of a straight-forward issue may find this process can yield quick, effective results. On the other hand, if the parent is dissatisfied with the result, there is no opportunity for appeal within the state's administrative structure or through a state or federal court.

\section{B. Quantitative Assessment}

I assessed the resolution of state complaints by the various state investigators and by school district. ${ }^{19} \mathrm{I}$ coded a resolution as "district prevails" if the district prevailed on every issue. ${ }^{20} \mathrm{I}$ coded a complaint resolution as "student prevails" if the student prevailed on every issue. And, I coded the complaint resolution as "mixed" if the student won on some, but not all, issues. (The above example would be listed as "mixed" under that coding scheme.) In coding the complaints as "student prevails," I did not take into account whether the student obtained exactly the relief that the student requested. It is possible that some parents would consider some of these cases not to be an actual victory, because the relief was too insignificant. Initially, I tried to classify the "mixed" category as either pro-student or prodistrict, but I could not establish any objective criteria for doing so. My

18 The investigative process, however, does sometimes result in a conclusion that the school district owes the child a certain number of hours of missed instruction. See, e.g., $C P$ 0048-2012, Findings Letter, OHIO DEP'T EDUC. 8 (May 10, 2012), http://www.edresourcesohio.org/wp-content/uploads/2013/07/CP-0048-2012.pdf

(ordering school district to provide missed hours of home instruction).

19 Complaint findings are available through the Ohio Department of Education's website. See EDRESOURCES OHIO, http://www.edresourcesohio.org/?slug=due-processdatabase (last visited on March 11, 2014).

${ }^{20}$ I did all the coding myself using SPSS. After completing all the coding, I checked each case for accuracy several months after the initial coding. 
subjective view is that parents would consider many of the complaints in the "mixed" category as being victories but I could not verify that subjective view by interviewing parents, because the complaints are confidential.

The following chart reflects the outcomes in these complaint investigations:

Table 1: Complaint Investigation Outcomes

\begin{tabular}{|l|l|l|}
\hline & Frequency & Percent \\
\hline Student Prevails & 18 & $22.2 \%$ \\
\hline Mixed & 34 & $42.0 \%$ \\
\hline District Prevails & 29 & $35.8 \%$ \\
\hline Total & 81 & $100.0 \%$ \\
\hline
\end{tabular}

As the above table reflects, students prevailed on all issues in $22.2 \%$ of complaints; districts prevailed on all issues in $35.8 \%$ of complaints. In $42.0 \%$ of complaints, students prevailed on some, but not all, issues. Whether one concludes that students are comparatively successful in these complaints depends on how one evaluates the $42.0 \%$ of complaints that resulted in mixed outcomes. As mentioned above, it was my subjective sense that the relief in many of these cases would have been considered satisfactory by the parent, but I did not conduct interviews to confirm that impression.

When I sorted the results by the name of the investigator or the school district, no significant differences appeared. The most cases were filed in two of the state's largest school districts-Cincinnati (eight) and Columbus (eight). Surprisingly, there was only one complaint filed against the Cleveland Metropolitan School District even though it is one of the state's largest school districts.

The quantitative results suggest that neither the school district nor the investigator is a significant factor that can predict the outcomes in these cases. The qualitative analysis is therefore more useful in helping us see what kinds of complaints are likely to attain some relief for the student.

\section{Qualitative Results}

There were six issues that seemed to be amenable to relief for the student through the complaint process: (1) who is in attendance at IEP meetings, (2) lack of parent communication/progress reports, (3) inadequate IEPs, (4) improper use of seclusion and restraint, (5) obligations of community schools, and (6) delays in evaluating students. 


\section{Who Should be in Attendance}

There were five complaints that involved the issue of who should be in attendance at IEP meetings. ${ }^{21}$ The IDEA regulations specify that the following individuals must be present at an IEP meeting: (1) the parents or guardian of the child, (2) a regular education teacher if the child participates in the regular education environment, (3) a special education teacher, (4) a representative of the school district who is knowledgeable about the availability of resources, (5) an individual who can interpret the test results, (6) others with appropriate expertise, and (7) where appropriate, the child with a disability.22

In four of the five cases investigated, the state investigator found that at least one of these individuals was not present at the meeting. In CP 00482012, investigator Laughlin found that the Cincinnati school district did not have present at least one regular education teacher or a district representative, and ordered a corrective action plan. ${ }^{23}$ In CP 0158-2012, investigator Laughlin found that the Bright Local School District failed to have a science teacher present to discuss the student's needs in that class; the school district re-convened the IEP team before the investigator even finished her investigation. ${ }^{24}$ In CP 0043-2013, investigator Drvota found that no one was present who could interpret speech test results; the school district was ordered to reconvene the IEP meeting and include an individual to interpret the speech evaluations and a special education teacher. ${ }^{25}$ Finally, in CP 00202013, investigator Cline found that the mother or grandmother needed to be invited to a meeting involving a 9-year-old boy who was in foster care. Nonetheless, in CP 0168-2012, investigator Laughlin found that certain individuals were properly excused from the IEP meeting.

21 CP 0048-2012, supra note 18; CP 0173-2013, supra note 14; CP 0168-2012, Findings Letter, OHIO DEP'T EDUC. (Dec. 5, 2012), http://www.edresourcesohio.org/wpcontent/uploads/2013/07/CP-0168-2012.pdf.; CP 0158-2012, Findings Letter, OHIO DEP'T EDUC. (Oct. 18, 2012) http://www.edresourcesohio.org/wpcontent/uploads/2013/07/CP-0158-2012.pdf ; CP 0043-2013, Findings Letter, OHIO DEP'T EDUC. (May 20, 2013), http://www.edresourcesohio.org/wpcontent/uploads/2013/07/CP-0043-2013.pdf; CP 0020-2013, Findings Letter, Оніо DEP'T EDUC. (Apr. 12, 2013), http://www.edresourcesohio.org/wpcontent/uploads/2013/07/CP-0020-2013.pdf.

2234 C.F.R. $\$ 300.321$ (2014).

${ }^{23} \mathrm{CP}$ 0048-2012, supra note 21, at 12.

${ }^{24} C P 0158-2012$, supra note 21 , at 3.

${ }^{25}$ CP 0043-2013, supra note 21 , at 8. 
The issue of who should be in attendance at IEP meetings, the issue in CP 0168-2012, is an excellent one for an investigation because it can largely be resolved by looking at the IEP itself. The IDEA has the following excusal rule for attendance at an IEP meeting. Required team members can be excused if:

(I) the parent and local educational agency consented to the excusal; and

(II) the member submits, in writing to the parent and the IEP team, input into the development of the IEP prior to the meeting. ${ }^{26}$

In CP 0168-2012, there was no doubt that the parent had signed a waiver. ${ }^{27}$ The issue was whether the second requirement could also be metthat the excused team members had provided input into the development of the IEP prior to the meeting. One way that school districts can satisfy the second requirement is to have the missing team members sign the section of the IEP labeled "People Not in Attendance Who Provided Information and Recommendations." 28 In this instance, however, the intervention specialist and the general education teacher did not sign that part of the IEP. Despite that lack of signature, the investigator found there was evidence that these individuals had provided input in advance of the IEP meeting because their views were reflected in the profile sections and the section concerning measurable goals and objectives. ${ }^{29}$

Attendance by appropriate team members is crucial to the IEP process so it is an important requirement for school districts to follow. Because the hearing officer process only orders relief when a procedural violation causes "substantive harm," 30 this issue is especially well-suited for the complaint process. The state department of education can be monitoring these kinds of attendance issues even if a remedy is not instituted for a particular student. As the investigator found in CP 0168-2012, "best practices" would have resulted in the excused team members signing the section of the IEP indicating they had provided input in advance..$^{31}$

One might argue that the relief ordered in successful complaints regarding this issue does not provide genuine assistance to the child. For example, a school district might be ordered to create a corrective action plan

\footnotetext{
2620 U.S.C. $\$ 1414$ (d)(1)(C)(ii) (20i2).

${ }^{27}$ CP 0168-2012, supra note 21 , at 7.

${ }^{28} \mathrm{Id}$. at 8.

${ }^{29} \mathrm{Id}$.

3020 U.S.C. $\$ 1415(f)(3)(E)(i i)$ (2012).

${ }^{31} \mathrm{CP} 0168-2012$, supra note 21 , at 8.
} 
but the IEP that was developed under these inappropriate circumstances might not be invalidated. ${ }^{32}$ Nonetheless, in three of the four cases discussed above, in which a violation was found, a new IEP meeting had been held, or was ordered to be held, as a result of the state investigative process. Had a due process hearing been necessary, it would have taken much longer to attain relief. Thus, it appears that the complaint investigation process can yield quick, effective relief in these kinds of cases.

\section{Lack of parent communication/progress reports}

There were many complaints involving problems with school district communication with the parents. ${ }^{33}$ One common problem is that school districts did not comply with the requirements for giving written notice to parents when certain conditions are met, like a decision not to initiate or change the identification of a child as disabled. ${ }^{34}$ This problem was found to exist in CP 0046-2012; investigator Cline found that the WilloughbyEastlake school district failed to send the parents written notice to explain why they denied a parent's request to classify a student as disabled. ${ }^{35}$ This kind of notice is crucial to parents knowing if they want to file a due process complaint regarding a failure to classify. As a result of the filing of this complaint, the school district undertook a multi-factor evaluation of the student, and also reconvened the student's Section 504 team to discuss the parent's concerns. ${ }^{36}$ The complaint investigation does not state if the school district decided to classify the student as disabled. If the school district declined to classify the student as disabled, the parent now has the information to understand the basis for this conclusion and, if necessary, can file a due process complaint with respect to this issue.

Another common problem is that school districts do not comply with rules regarding parent participation at IEP meetings. ${ }^{37}$ School districts "must

32 CP 0048-2012, supra note 18 , at 12.

33 See, e.g., CP 0045-2012, Findings Letter, Оноо DEP'T EDUC. (May 8, 2012), http://www.edresourcesohio.org/wp-content/uploads/2013/07/CP-0045-2012.pdf; $\quad C P$ 0048-2012, supra note 18; CP 0064-2012, Findings Letter, OHIO DEP'T EDUC. (May 24, 2012), http://www.edresourcesohio.org/wp-content/uploads/2013/07/CP-0064-2012.pdf; $C P$ 0046-2012, Findings Letter, OHIO DEP'T EDUC. (May 8, 2012), http://www.edresourcesohio.org/wp-content/uploads/2013/07/CP-0046-2012.pdf.

34 See 34 C.F.R. $\S 300.503$ (2014).

${ }^{35}$ CP 0046-2012, supra note 33 , at 3 .

${ }^{36} \mathrm{Id}$.

37 See 34 C.F.R. \& 300.222 (2014). 
take steps to ensure that one or both parents of a child with a disability are present at each IEP Team meeting or are afforded the opportunity to participate." 38 This issue arose in CP 0091-2012, where the parent alleged that the school district held a meeting on March 27, 2012 even though she had requested that the meeting be rescheduled to allow her time to consult with an advocate. ${ }^{39}$ The school district held the meeting on March 27, 2012 in order to comply with the sixty-day time line for completing the evaluation. Investigator Cline found that the school district was not in violation of the IDEA because it also encouraged the parent to attend subsequent meetings to discuss the student's needs with regard to a Section 504 plan. ${ }^{40}$ On the other hand, investigator Monica Drvota did find a violation of parental communication requirements in CP 0045-2012, when the school district failed to contact the parent via telephone or reconvene the IEP to review and revise the IEP based on the student's poor performance. ${ }^{41}$ Before the investigative process was completed, the IEP team reconvened to review and revise the student's IEP with parent participation. ${ }^{42}$ The investigator stated that this action "would have been part of the corrective action for this issue." 43

A related rule was found to be violated when the Norwood school district called the parent the morning of a manifestation meeting to invite the parent to attend the meeting. ${ }^{44}$ In the Norwood case, the school district was also chided for placing progress reports and other communications in the student's backpack rather than mailing communications. ${ }^{45}$ Those cases lent themselves to the investigation process because they could be resolved on the basis of paper records. A recent Ninth Circuit case highlights the importance of school districts scheduling IEP meetings so that parents can attend. ${ }^{46} \mathrm{~A}$ failure to reschedule a meeting so that a parent or guardian can attend can constitute a due process violation. ${ }^{47}$

38 See C.F.R. $\$ 300.322$ (2014).

39 CP 0091-2012, Findings Letter, OHIO DEP'T EDUC. 6 (June 26, 2012), http://www.edresourcesohio.org/wp-content/uploads/2013/07/CP-0091-2012.pdf.

${ }^{40}$ Id. at 7.

${ }^{41}$ CP 0045-2012, supra note 33, at 11.

42 Id.

$43 \mathrm{Id}$.

${ }^{44}$ See CP 0064-2012, supra note 33, at 3.

45 Id . at 14.

46 Doug C. v. Haw. Dep't of Educ., 720 F.3d 1038, 1045 (9th Cir. 2013).

${ }^{47} \mathrm{Id}$. 
In this case, one might argue that the relief provided by the investigator was inadequate. At the manifestation meeting, where the parent was not in attendance, the team decided that the behavior was not a manifestation of the student's disability and the student was placed on home instruction. 48 The investigator found the school did not violate the rules regarding manifestation determinations because the team answered the appropriate questions and the student was not expelled. ${ }^{49}$ The relevance of the fact that the student was not expelled is unclear; the student was suspended and placed on home instruction. Nonetheless, the investigator found that the parent should be given a chance to participate at the February 28, 2012 IEP meeting..$^{50}$ The school district was ordered to "take steps to ensure the parent is afforded the opportunity to participate in the IEP meeting." 51 In the due dates for corrective action, at the end of the findings, however, the investigator does not provide a date for such a meeting.52 Presumably, a meeting was held sometime after the investigation was completed on May 24, 2012.

It is hard to know if the relief provided in this case was less than could have been obtained at a due process hearing. At a due process hearing, the hearing officer has to determine if a procedural violation resulted in one of three types of harms. ${ }^{53}$ Possibly, the investigator was implying that the procedural violation did not cause a deprivation of educational benefits because she thought the same decision would have been reached even if the parent were present, and she thought that the opportunity for home instruction did not constitute a deprivation of educational benefits. Clearly, the investigator provided no substantive relief for the period of suspension. At a due process hearing, if the hearing officer concluded the suspension was inappropriate, then there could have been an award of compensatory

${ }^{48}$ CP 0064-2012, supra note 33 , at 2.

$49 \mathrm{Id}$. at 4.

$50 \mathrm{Id}$.

51 Id. at 3.

52 Id. at 14-15.

${ }^{53}$ See 20 U.S.C. $\S 1415(f)(3)(E)(i i)$. The three types of harms are:

(I) Impeded the child's right to a free appropriate public education;

(II) Significantly impeded the parents' opportunity to participate in the decision-making process regarding the provision of a free appropriate public education to the parents' child; or

(III) Caused a deprivation of educational benefits.

Id. 


\section{SPECIAL EDUCATION COMPLAINT RESOLUTION}

education. In this instance, the complaint process did not generate significant relief on that issue.

\section{Inadequate IEPs}

The IDEA has various requirements for the content of a student's Individualized Educational Program ("IEP"). Those include:

(1) A statement of the child's present levels of academic achievement and functional performance ....

(2) A statement of measurable annual goals, including academic and functional goals ....

(3) A description of ---

(i) How the child's progress toward meeting the annual goals described in paragraph (2) of this section will be measured; and

(ii) When periodic reports on the progress the child is making toward meeting the annual goals ... will be provided;

(4) A statement of the special education and related services and supplementary aids and services ... be provided to the child, or on behalf of the child, and a statement of the program modifications or supports for school personnel that will be provided to enable the child [to meet his or her annual goals]. 54

Some key aspects of these rules are that the school (rather than merely the parent or student) must be providing these services. The statements of goals and progress must be based on individualized data. The goals must be sufficiently precise that they can be implemented. State investigators found that six school districts failed to meet these basic requirements for IEPs. ${ }^{55}$

5434 C.F.R. $\S 300.320(a)(1)$.

55 See CP 0098-2012, Findings Letter, OHIO DEP'T EDUC. (June 28, 2012), http://www.edresourcesohio.org/wp-content/uploads/2013/07/CP-0098-2012.pdf; CP 01502012, Findings Letter, Оно DEP'T EDUC. (Sept. 14, 2012), http://www.edresourcesohio.org/wp-content/uploads/2013/07/CP-0150-2012.pdf; CP 01682012, supra note 21; CP 0173-2012, Findings Letter, OHO DEP'T EDUC. (Dec. 10, 2012), http://www.edresourcesohio.org/wp-content/uploads/2013/07/CP-0173-2012.pdf; CP 02312012, Findings Letter, OHIO DEP'T EDUC. (Mar. 4, 2013), http://www.edresourcesohio.org/wp-content/uploads/2013/07/CP-0231-2012.pdf; CP 01702012, Findings Letter, OHIO DEP'T EDUC. (Nov. 16, 2012), http://www.edresourcesohio.org/wp-content/uploads/2013/07/CP-0170-2012.pdf. 
The first type of error-failing to put the responsibility on the school rather than the parent or child-was found in CP 0098-2012.56 Investigator Drvota found that Strongsville School District created an IEP that put the onus on the student, rather than the school, to provide assistance. The student was supposed to solve his organizational problems by taking personal responsibility for being more organized. That IEP violated the basic rule that an IEP is supposed to be about the resources that the school district will devote to the student. In response to the complaint, the school district revised and re-wrote the goals and objectives, which is the corrective action that would have been otherwise ordered..$^{57}$

Similarly, investigator Cline found that the Heir Force Community School failed to develop an appropriate IEP when its behavior plan was to send the student home from school when he misbehaved. ${ }^{58}$ That kind of plan says nothing about the direct instruction offered by the school to encourage appropriate behavior. Further, Cline found that that IEP did not contain measurable goals and objectives. As relief, Cline indicated that she ordinarily would have required the school to reconvene the student's IEP team. In this instance, however, the student was no longer enrolled in the school. ${ }^{59}$

Finally, investigator Laughlin found that the Hilliard School District failed to develop an IEP that described the resources that the school district, rather than the parent or student, devoted to solving an issue. ${ }^{60}$ For example, the IEP stated that the "parent agrees to implement more tools to help the student not get overwhelmed and work with counselors on a treatment plan."61 Again, that plan says nothing about the direct instruction offered by the school to help the student advance academically. ${ }^{62}$ As relief, the investigator required the school district to offer an intervention to the student and forward a copy of the intervention plan or the draft plan to the state

${ }^{56}$ CP 0098-2012, supra note 55, at 2.

$57 \mathrm{Id}$.

58 CP 0231-2012, supra note 55, at 9.

59 Id. at 6-7.

60 CP 0153-2012, Findings Letter, OHIO DEP'T EDUC. 6-7 (Oct. 2, 2012), http://www.edresourcesohio.org/wp-content/uploads/2013/07/CP-0153-2012.pdf.

${ }^{61}$ Id.at 4.

62 A similar error sometimes found on an IEP is a failure of the IEP to identify a placement based on the student's individual needs. In CP 0168-2012, supra note 21 , at 27 , for example, investigator Laughlin found that the placement decision was based on the student's generic disability rather than the unique needs of the student as identified in the IEP. 


\section{SPECIAL EDUCATION COMPLAINT RESOLUTION}

office by November 2, 2012 (one month after the investigation was completed). ${ }^{63}$

The second type of error-failure to collect and apply sufficient datawas found in five complaints. ${ }^{64}$ In CP 0150-2012, Newbury School District used generic forms that had no data for specific students. ${ }^{65}$ That kind of error is inconsistent with the requirement that IEPs be individualized. In CP 01682012, investigator Laughlin found that the Hilliard School District was using annual goals that were too vague. ${ }^{66}$ For example, one original IEP goal said: "Given a writing prompt, student will write a response in a complete sentence. $75 \%$ mastery." 67 Following the investigation, the IEP goal was rewritten to say: "Given a writing prompt of a familiar subject, student will independently write a response of 1-4 sentences using correct spelling, punctuation, form and proper spacing."68 Similarly, in CP 0173-2012, investigator Laughlin found that Hilliard's annual goals were too general. ${ }^{69}$ The original IEP goal said: "Student will demonstrate understanding and use of language. $80 \%$ mastery."70 The revised IEP said: "The student will verbally state grammatically correct sentences to define, describe and express herself with details in the therapy setting."71 In these types of cases, it appears that the filing of the complaint spurs the school district to revise the IEP to meet legal standards.

It is somewhat surprising that the state investigative process would be used to determine that IEP goals are inadequate because such issues are usually determined under a subjective test governed by Board of Education

${ }^{63}$ CP 0153-2012, supra note 60, at 7.

64 See CP 0150-2012, supra note 55; CP 0168-2012, supra note 21; CP 0173-2012, supra note 55; CP 0038-2013, Findings Letter, OHIO DEP'T EDUC. (May 10, 2013), http://www.edresourcesohio.org/wp-content/uploads/2013/07/CP-0038-2013.pdf; $\quad C P$ 0246-2012, Findings Letter, OHIO DEP'T EDUC. (Feb. 28, 2013), http://www.edresourcesohio.org/wp-content/uploads/2013/07/CP-0246-2012.pdf.

${ }^{65}$ CP 0150-2012, supra note 55, at 1.

66 CP 0168-2012, supra note 21 , at 21.

${ }^{67} \mathrm{Id}$. at 19.

68 Id. at 20.

${ }^{69}$ CP 0173-2012, supra note 55, at 16.

${ }^{70} \mathrm{Id}$. at 6.

71 Id. at 15 . Similarly, in CP 0038-2013, supra note 64 , at 9, the state investigator found that the goals were too general with statements such as "student will develop, practice and use strategies to answer comprehension questions." In CP 0246-2012, supra note 64 , at 6 , the investigator found that the IEP contained no measurable goals or clear roles for professionals. 
v. Rowley $y^{72}$ that the student must receive a free and appropriate education..$^{73}$ In both of these examples, however, one does not need to review expert testimony about the student to determine the IEP goals were inappropriate because they failed to meet the requirement that the annual goals be "measurable."74 The goals were too vague to be subject to measurement. There would be no way to create a rubric to determine if the student had met the goal because of imprecision in the goal itself. The willingness of a state investigator to conclude that goals are not appropriate is an important protection for students due to the speed of the state investigative process. This problem can be identified and solved within an academic year. In fact, the problem often seems to have been solved before the investigator issued her report.

\section{Improper use of seclusion and restraint}

There were two investigations regarding allegations of seclusion and restraint in the data base, both done by the same investigator, with quite different results.

The first complaint was resolved by investigator Cline on January 11, 2013 and involved allegations brought against Columbus City Schools. ${ }^{75}$ It was a complaint brought on behalf of one individual child as well as 375 students by Disability Rights Ohio, involving 1800 incidents of seclusion and restraint. The investigator found that the complaint did not establish the existence of a denial of a free appropriate public education for any students. The complaint raised issues that would seem to have been safety problems that would preclude the existence of an appropriate education such as inadequate square footage (nineteen square feet in one room); closet-like structures with a mere peep hole, unsafe storage items such as electronic equipment, fans and metal cabinets; extended seclusion for more than five minutes; dangerous single-person restraints; and dangerous prone restraints. The difficulty with this complaint may be that it required an expert to evaluate the practices. Further, at the time, Ohio had no policies for the use of seclusion and restraint to determine if the practices were appropriate. ${ }^{76}$

72458 U.S. 176 (1982).

73 See 20 U.S.C. $\$ 1412(\mathrm{a})(1)$.

7434 C.F.R. $\S 300.320(\mathrm{a})(2)(\mathrm{i})$.

75 CP 0203-2012, Findings Letter, OHIO DEP'T EDUC. (Jan. 11, 2013), http://www.edresourcesohio.org/wp-content/uploads/2013/07/CP-0203-2012.pdf.

76 See Policy on Positive Behavior Interventions and Support, and Restrain and Seclusion, OHIO DEP'T EDUC. (Jan. 15, 2013), http://education.ohio.gov/ 
By contrast, investigator Cline found that Heir Force Community School had engaged in restraint that was in violation of the IDEA. ${ }^{77}$ Unlike the complaint against Columbus, this complaint involved a single student. The investigator found that school staff members restrained the first-grade student frequently and had "one person carry the student to the office or other locations when he refused to move."78 The investigation documented that a teacher sat on the student's chest which investigator Cline described as "potentially lethal." " In fact, Cline filed a complaint with Children's Services over alleged abuse of this student. It is not clear why Cline reacted so strongly to use of force against this student but found no violations when similar conduct was documented against the City of Columbus. The complaint process is specifically designed to reach class-wide issues so that aspect of the Columbus complaint should not have been problematic.

Possibly, this is an example of relief that is available in theory, but not in practice. It is easier for an investigator to assess a situation when a complaint involves only one individual student. Civil litigation, with its class action tools, may be better suited to the kind of relief sought through this complaint. Further, the investigative complaint process does not permit appeals, so it resulted in a dead end for Disability Rights Ohio, once the investigator found in favor of the school district. With new policies in effect in Ohio regarding seclusion and restraint, class-wide claims may be more viable in the future, because complainants can point to a specific policy that is not being followed.

\section{Community Schools}

Community schools (or what other states call "charter schools") are subject to the IDEA as public schools. ${ }^{80}$ Nonetheless, community schools do not always seem to recognize that fact. There were three successful

getattachment/Topics/Other-Resources/School-Safety/Building-Better-Learning-

Environments/Policy-Positive-Behavior-Interventions-and-Support/Ohio-Department-ofEducation-Policy-on-Positive-Behavior-Interventions.pdf.aspx

${ }^{77}$ CP 0231-2012, supra note 55, at 9.

$78 \mathrm{Id}$.

${ }^{79} \mathrm{Id}$.

80 The IDEA applies to all public schools and community schools are publicly funded. See Ohio's Primer on Special Education in Community Schools, OHIO DEP'T EDUC. (Sep. 2008), http://education.ohio.gov/getattachment/Topics/SchoolChoice/Community-Schools/Special-Education-Primers-for-Ohio\%E2\%80\%99sCommunity-Sch/OH-CS-Background-Primer-9-08.pdf.aspx 
complaints against community schools in this database. In CP 0231-2012, investigator Cline noted that community schools have an obligation to teach students with disabilities rather than force them to withdraw. ${ }^{81}$ Similarly, in CP 0030-2012, investigator Rensch found that a community school had failed to prepare proper IEPs and have sufficient placement options. ${ }^{82}$ Finally, in CP 0042-2012, investigator Petrasek found that a community school was not equipped to provide specialized services. ${ }^{83}$

The complaint process is well-suited to a basic task like reminding community schools in Ohio that they must comply with the IDEA. In these cases, it appears that the community schools were disregarding their IDEA obligations. The state instituted stringent oversight to make sure that the IDEA was followed in the future. The violations in CP 0231-2012 were considered to be so serious that the investigator indicated that her department would "conduct an on-site visit to the community school to interview teaching, support and administrative staff concerning the continuum of placements available at the community school and the training provided to and available to staff who may be in a situation where a student may need to be restrained to prevent harm to the student or others." 84

\section{Delay in Evaluating Students}

On January 11, 2011, the United States Department of Education issued an opinion letter saying, "It would be inconsistent with the evaluation provisions at 34 C.F.R. $\S 300.301$ through 300.111 for an LEA to reject a referral and delay provision of an initial evaluation on the basis that a child has not participated in an RTI framework." 85 The reference to an "RTI framework" is a reference to special rules about determining whether students have a specific learning disability. A school district "may use a process that determines if the child responds to scientific, research-based intervention as part of the evaluation procedures described in paragraphs (2)

${ }^{81}$ CP 0231-2012, supra note 55, at 6.

82 CP 0030-2013, Findings Letter, OHIO DEP'T EDUC. 3 (Apr. 12, 2013), http://www.edresourcesohio.org/wp-content/uploads/2013/07/CP-0030-2013.pdf.

83 CP 0042-2012, Findings Letter, OHо DEP'T EDUC. 1-2 (May 7, 2012), http://www.edresourcesohio.org/wp-content/uploads/2013/07/CP-0042-2012.pdf.

84 CP 0231-2012, supra note 55, at 10.

85 See Memorandum from Melody Musgrove, Dir., Office of Special Educ. Programs 3 (Jan. 21, 2011), available at http://www2.ed.gov/policy/speced/guid/idea/ memosdcltrs/osep 11-07rtimemo.pdf. 
and (3)." 86 In Ohio, school districts have sixty days to complete an evaluation to determine if a student is disabled once the parent provides consent for the student to be evaluated. ${ }^{87}$

Despite this clear opinion letter, it was common for parents to complain that interventions were delayed in violation of the IDEA. Investigators often found in favor of the student in these cases. ${ }^{88}$ Nonetheless, the investigators also sometimes found in favor of the school districts. ${ }^{89}$ Unfortunately, it is difficult to reconcile these decisions other than to note that the more recent decisions are more likely to find violations than the older decisions. For example, in CP 0168-2012, investigator Rochelle Rensch found that the Hilliard City School District did not violate the Child Find policies and procedures when it failed to refer a student for evaluation until February 13, 2012.90

This student had a long history of not meeting grade-level expectations. Because the complaint was filed on September 15, 2012, the complaint investigation was limited to one year prior to that date-September 15, 2011 (beginning of second grade). Prior to entering kindergarten in 2009, the student failed to meet the readiness screener. ${ }^{91}$ The student was provided reading interventions in first and second grade, but did not receive an evaluation under IDEA until February of second grade. The only previous evaluation appears to have been in August of 2006 when the student was entering preschool. When an evaluation was finally conducted in March

8620 U.S.C. $\S 1414(\mathrm{~b})(6)(\mathrm{B})$.

${ }^{87}$ See Request and Referral for Initial Evaluation, OHIO DEP'T OF EDUC. (Nov. 25, 2013), http://education.ohio.gov/Topics/Special-Education/Federal-and-StateRequirements/Procedures-and-Guidance/Evaluation/Request-and-Referral-for-InitialEvaluation.

88 See CP 0016-2013, Letter of Findings, OHIO DEP'T EDUC. (Apr. 1, 2013), http://www.edresourcesohio.org/wp-content/uploads/2013/07/CP-0016-2013.pdf; $\quad C P$ 0023-2013, Findings Letter, OHIO DEP'T EDUC. (Apr. 17, 2013), http://www.edresourcesohio.org/wp-content/uploads/2013/07/CP-0023-2013.pdf; $\quad C P$ 0230-2012, Findings Letter, OHIO DEP'T EDUC. (Apr. 23, 2013), http://www.edresourcesohio.org/wp-content/uploads/2013/07/CP-0230-2012.pdf; $\quad C P$ 0014-2013, Findings Letter, OHIO DEP'T EDUC. (Mar. 27, 2013), http://www.edresourcesohio.org/wp-content/uploads/2013/07/CP-0014-2013.pdf.

89 See CP 0182-2012, Findings Letter, OHо DEP'T EDUC. (Nov. 28, 2012), http://www.edresourcesohio.org/wp-content/uploads/2013/07/CP-0182-2012.pdf.

${ }^{90}$ CP 0168-2012, supra note 21 , at 5 .

91 Id. at 3. 
2012 , the student was classified as disabled under the category of "cognitive disabilities." 92

The parent argued that the school district unduly delayed the student's evaluation in violation of Melody Musgrove's memorandum of January 21, 2011, which instructed school districts not to use RTI strategies to delay or deny the provision of a student evaluation. ${ }^{93}$ In this instance, there was no evaluation between August 2006 and March 2012 while the school district implemented various support programs for the student. Because the investigator can only investigate a one-year time period from the date the complaint was filed, she only went back to September 2011 for the purpose of this investigation. She concluded that there was no evidence that the school district suspected the student had a disability prior to the February 2012 referral, and that it was reasonable to offer classroom support for that time period before deciding to evaluate the student. ${ }^{94}$

The problem with this determination is that, based on the evaluation that was eventually conducted, it is implausible to believe that this student's classroom teachers did not have strong evidence of this student's disability. For example, her math skills were described as "extremely basic. She can write individual numbers and can add single digit numbers with no carrying. She cannot subtract." $95 \mathrm{Her}$ reading comprehension was described as "significantly limited" and her writing skills were described as "limited."96 She was not found to have a specific learning disability in only one subject area; instead, she was found to have an overall cognitive disability. Although her parents may not have triggered a child find obligation by specifically requesting an evaluation, it is hard to imagine why her classroom teachers did not have ample evidence of significant difficulty in all subject areas to request an evaluation. By focusing on the time period of the investigation, the investigator loses sight of the cumulative evidence available to each classroom teacher. Further, the investigator's logic seems to suggest that delays can rarely be found given the one-year limitation in the time frame of an investigation.

By contrast, investigators found unlawful delays in evaluating students in three cases that were decided in April 2013. In CP 0016-2013, the Cincinnati Public Schools was found to have unlawfully delayed an evaluation while it sought to implement a behavior plan. The state investigator found: "The
92 Id. at 4.
${ }^{93} \mathrm{Id}$. at 5 .
94 Id. at 5-6.
95 Id. at 9.
96 Id. at 9. 
district used the FBA and the BSP to delay this student's evaluation for nearly one year without providing data which demonstrated that the BSP was providing an educational benefit to the student."97 In this case, the parent asked for an evaluation on February 28, 2012 and the school district did not agree to conduct an evaluation until January 17, 2013. Unlike CP 0168-2012, there is evidence of a written request by the parent for an evaluation. But, even absent a written request from the parent, a school district has an obligation to engage in "child find."98 School district instigation of its child find obligation should not be dependent on the parent requesting an evaluation.

In CP 0023-2013, the investigator used very strong language to conclude that the school district had unlawfully delayed an evaluation. ${ }^{99}$ As in CP 0016-2013, the parent put in writing a request for an evaluation. This request was made on September 26, 2012. The school district responded that it typically does interventions for six to eight weeks before agreeing to an evaluation. ${ }^{100}$ The school district agreed to conduct an evaluation on January 30,2013 . The investigator found the school district was not in compliance with its child find requirements, finding there cannot be a " $6-8$ weeks requirement for interventions prior to an evaluation."101

Finally, in CP 0230-2012 a state investigator found an unlawful delay when a school district refused to conduct an evaluation of a student who had previously been found ineligible for special education. ${ }^{102}$ As in the previous two cases, the investigator emphasized "that" interventions cannot be utilized to deny a needed evaluation."103 This case is difficult to reconcile with CP 0168-2012, in which no unlawful delay was found, because both cases involved the same investigator. The crucial difference may be that the parent in CP 0230-2012 put his or her request for an evaluation in writing.

CP 0230-2012 is also very interesting for another reason. The parent in this case had filed a due process complaint that was dismissed.104 The complaint process, however, was quite successful and, unlike CP 0168-2012, the investigator may have reviewed factual information beyond the one-year time limit of a complaint investigation. The investigator states that the

97 CP 0016-2013, supra note 88, at 7.

9820 U.S.C. $\$ 1412(a)(3)$ ("Child find" obligations).

${ }^{99} \mathrm{CP}$ 0023-2013, supra note 88 , at 5 .

100 Id. at 3.

101 Id. at 5.

102 CP 0230-2012, supra note 88 , at 8.

103 Id. at 9.

104 Id. at 1. 
complaint investigation began on February 25, 2013 when the office was informed that the due process complaint, SE 2773-2013, was dismissed. The state complaint had been put in abeyance pending the resolution of the due process complaint. Unfortunately, the investigator does not state the date on which the initial state complaint was filed so that one can determine the timing of the one-year statute of limitations. ${ }^{105}$

In this case, the school district had conducted an evaluation of the student in December 2011 and concluded that the student was not disabled. The investigator reviewed the December 2011 evaluation and characterized it as "deficient" and "not sufficiently comprehensive."106 The investigator found that the school district was in violation of the IDEA with respect to the December 2011 evaluation. ${ }^{107}$ The investigator does not state when the complaint was filed so it is impossible to determine if December 2011 was within one year of the date of the complaint.

In October 2012, the parent requested a new evaluation to determine if the student was disabled and the school district responded that an evaluation could not occur since the student had been evaluated less than a year ago. The investigator, however, found that the school district was incorrect because the student had not been classified as disabled as a result of the December 2011 evaluation. The re-evaluation rule only applies when a student has already been classified as disabled. ${ }^{108}$

As a result of the state complaint, the investigator created an extensive corrective action plan. In addition to creating a supervision plan to make sure the school district is complying with the child find requirements in the future, the investigator also required the school district to "document the offer of summer services to the student" to "address any lack of progress during the 2012-2013 school year." 109 Thus, despite the dismissal of the due process hearing complaint, the student appears to have attained quite full relief.

105 Most of the complaint investigations do not state the date of the filing of the complaint. That information would be useful so that the reader can better understand the scope of the investigation.

${ }^{106} \mathrm{CP}$ 0230-2012, supra note 88 , at 7 .

107 Id. at 9.

108 Id. at 8.

${ }^{109} I d$. at 10. 


\section{Due Process Hearing Results}

\section{A. Background}

It is difficult to follow due process hearing results in Ohio because the state is erratic in posting them on its website. Further, the state does not use a consistent format for writing its decisions and does not use a consistent process for redacting identifying information. Finally, the bare information that is posted on the state's website does not necessarily accurately reflect the dates of the posted decisions.

In June 2013, when I decided to read hearing officer decisions issued over the last year, I soon learned that the state had not posted any decisions since May 2012 even though the Department of Education's Operating Standards state that the decisions must be made "available to the public." 10 In other words, there were no decisions available to read. After requesting these decisions be posted, the state finally posted a few decisions in July 2013.

As of December 16, 2013, the state of Ohio has posted seven decisions under the year "2013." One of those decisions is listed as 2013 even though it was decided in 2012."11 Further, four of the cases labeled as "2012" were actually decided in 2013. ${ }^{112}$ Finally, I am aware of one case decided on August 8, 2013 that has not yet been posted on the state's database. ${ }^{113}$ I

110 See STATE BD. EduC. OHIO, supra note 13, at $\$ 3301-51-05(\mathrm{~K})(13)(\mathrm{d})(\mathrm{ii})$.

111 One case is captioned as SE 2603-2012 but it is actually a state level review officer decision and should be captioned as SLR 2603-2012. It is listed on the website as a 2013 decision with the case number as SLR 2603-2012. In fact, the case was decided on October 23, 2012. This case therefore reflects two errors-the year is wrong on the website and the caption is wrong on the date itself. I brought these errors to the attention of the state of Ohio in December 2013 but the errors remained as of February 13, 2014.

112 Student v. Cleveland Metro. Sch. Dist., SLR 2702-2012 (Ohio Dep't of Educ. State Level Review Officer [hereinafter SLRO] Theresa L. Hagen Feb. 21, 2013), available at http://www.edresourcesohio.org/wp-content/uploads/2013/09/SLRO-27022012.pdf; Student v. Toledo Pub. Sch., SLR 2609-2011 (Ohio Dep't of Educ. SLRO Monica L. Bohlen June 2, 2013), available at http://www.edresourcesohio.org/wpcontent/uploads/2013/07/SLR-2609-2011.pdf; Student v. Green Local Sch. Dist., SE 2662-2012 (Ohio Dep't of Educ. State Impartial Hearing Officer [hereinafter IHO] Ronald Alexander Feb. 4, 2013), available at http://www.edresourcesohio.org/wpcontent/uploads/2013/07/SE-2662-2012.pdf; Student v. Toledo Pub. Sch., SE 2703-2012 (Ohio Dep't of Educ. IHO Matthew J. Rohrbacher), available at http://www.edresourcesohio.org/wp-content/uploads/2013/07/SE-2703-2012.pdf.

113 See Student v. Strongsville City Sch., SE 2715-2012 (Ohio Dep't of Educ. IHO Ronald Alexander Aug. 14, 2013), available at http://www.edresourcesohio.org/wp- 
brought these errors to the attention of the state of Ohio on December 17, 2013 but, as of February 13, 2014, those errors have gone uncorrected.

Of the eleven decisions rendered in 2013, eight were rendered by firstlevel hearing officers. ${ }^{114}$ Parents (and their child) prevailed, at least in part, in five of those cases. ${ }^{115}$ Three decisions were rendered by state level review officers. ${ }^{116}$ The parents (and their child) were able to maintain the bulk of their recovery in one case even after the state level review officer overturned part of the decision. ${ }^{117}$ In the other two cases, the state level review officer affirmed the decision below in favor of the school district. 118

content/uploads/2014/05/SE-2715-2012.pdf. See Due Process Decisions, OHIO DEP'T EDUC. OFFICE FOR EXCEPTIONAL CHILDREN, http://www.edresourcesohio.org/dueprocess-decisions/ (last visited Apr. 16, 2014).

114 The eight cases are Strongsville City Sch., SE 2715-2012 (pro-district); Green Local Sch. Dist., SE 2662-2012 (pro-parent); Student v. Hudson City Sch. Dist., SE 2802-2013 (Ohio Dep't Educ. IHO Todd Mazzola June 17, 2013) (partially pro-parent), available at http://www.edresourcesohio.org/wp-content/uploads/2013/07/SE-2802-2013.pdf; Student v. Wilmington City Sch., SE 2804-2013E (Ohio Dep't Educ. IHO Linda Warner Apr. 22, 2013) (pro-district), available at $\mathrm{http} / / \mathrm{www}$.edresourcesohio.org/wpcontent/uploads/2013/07/SE-2804-2013E.pdf; Student v. Maple Heights City Sch., SE 2803-2013 (Ohio Dep't Educ. IHO Ronald Alexander Nov. 7, 2013) (pro-parent), available at http://www.edresourcesohio.org/wp-content/uploads/2013/12/SE-28032013.pdf; Toledo Pub. Sch., SE 2703-2012 (pro-district); Parent v. Youngstown City Sch. Dist., SE 2814-2013 (Ohio Dep't Educ. IHO Ronald Alexander Sept. 13, 2013) (proparent), available at http://www.edresourcesohio.org/wp-content/uploads/2013/12/SE2814-2013.pdf; Student v. Mason Sch. Dist., SE 2784-2013 (Ohio Dep't Educ. IHO Tobie Braverman July 29, 2013) (pro-parent), available at http://www.edresourcesohio.org/wp-content/uploads/2013/09/SE-2784-2013.pdf.

115 See supra note 114. When I say parents (and their children) "prevailed," I used the same definition that I used in my earlier work on this issue. See supra note 5 . If the parents (and their children) prevailed on some, but not all issues, I labeled the case as parent prevailing. As we will see in the discussion that follows, the relief attained in some of these cases was often quite modest. Thus, I may be overstating the parent's own sense of whether they prevailed in these cases.

116 Student v. Green Local Sch. Dist., SLR 2662-2012 (Ohio Dep't Educ. SLRO Monica Bohlen May 22, 2013), available at http://www.edresourcesohio.org/wpcontent/uploads/2013/07/SLR-2662-2012.pdf; Student v. Strongsville City Sch. Dist, SLR 2603-2012 (Ohio Dep't Educ. SLRO Theresa Hagen Oct. 23, 2012), available at http://www.edresourcesohio.org/wp-content/uploads/2013/07/SLR-2603-2012.pdf;

Toledo Pub. Sch., SLR 2609-2011.

117 Green Local Sch. Dist., SLR 2662-2012 at 58-60.

118 Strongsyille City Sch. Dist., SLR 2603-2012 at 19; Toledo Pub. Sch., SLR 2609-2011 at 27. 
Although the state's recordkeeping is incomplete and inaccurate, it appears that the number of due process decisions has been declining in recent years. I am aware of only six cases decided in 2012 (after I transferred four cases out of the 2012 list to 2013 and put one case marked as 2013 into 2012). ${ }^{119}$ Of these six cases, four of them were decided pro-district. ${ }^{120}$ In 2011, I was able to locate thirteen decisions and only two students prevailed on minor aspects of their cases. ${ }^{121}$ Cumulatively, in 2011 and 2012, students prevailed in only three of nineteen cases $(15.8 \%)$.

In an earlier work, I investigated Ohio's hearing officer due process decisions for the time period 2002 through 2006, locating eighty-six decisions. ${ }^{122}$ There were fifty-five hearing officer decisions in the database for that time period; parents (and their child) prevailed in eighteen of those cases $(32.7 \%)$. There were thirty-one appeals to state level review officers. Parents (and their child) prevailed in eight of those cases $(25.8 \%)$. Overall, parents (and their child) prevailed (at least in part) in $30.0 \%$ of cases.

These are the results over time:

Table 2: Due Process Decisions Over Time

\begin{tabular}{|c|c|c|c|c|}
\hline Year & Pro-district & Pro-student & Total & $\begin{array}{c}\text { Percentage } \\
\text { Pro-student }\end{array}$ \\
\hline $2002-2006$ & 60 & 26 & 86 & $30.2 \%$ \\
\hline 2011 & 11 & 2 & 13 & $15.3 \%$ \\
\hline 2012 & 4 & 2 & 6 & $33.3 \%$ \\
\hline 2013 & 5 & 6 & 11 & $54.5 \%$ \\
\hline
\end{tabular}

119 See supra notes $111,112$.

${ }^{120}$ Toledo Pub. Sch., SE 2609-2011 (pro-district), Student v. Strongsville City Sch. Dist., SE 2603-2011E (Ohio Dep't Educ. IHO Tony Mazzola May 10, 2012) (pro-district), available at http://www.edresourcesohio.org/wp-content/uploads/2013/07/SE-26032011E.pdf, Student v. Strongsville City Sch. Dist., SE 2645-2011 (Ohio Dep't Educ. IHO Harry Taich May 23, 2012) (pro-district), available at http://www.edresourcesohio.org /wp-content/uploads/2013/07/SE-2645-2011.pdf, Student v. Cleveland Metro Sch. Dist., SE 2702-2012 (Ohio Dep't Educ. IHO Harry Taich Oct. 29, 2012) (pro-parent), available at http://www.edresourcesohio.org/wp-content/uploads/2013/07/SE-2702-2012.pdf, Toledo Pub. Sch., SLR 2609-2011 (pro-district), Cleveland Metro Sch. Dist., SLR 27022012 (affirming pro-parent decision in SE 2702-2012)).

121 There were numerous errors in the labeling of the years of the decisions as well as three broken links. Because of the high rate of errors in the database, these numbers are only estimates.

122 COLKER, supra note 4, at 148-49. 
The seeming uptick in the rate of success for parents (and their children) in 2013 is probably due to a small numbers problem. If we combine the 2011 to 2013 data, we find that parents (and their child) had a 33.3\% success rate (ten of thirty), virtually indistinguishable from the $30.2 \%$ rate from the time period 2002-2006. The number of cases decided per year, however, seems to have declined. From 2002 to 2006, there was an average of seventeen cases decided per year. For 2011-2013, there was an average of ten cases decided per year.

Many factors could be causing the decline in the number of decided cases. Because of the low success rate at due process hearings, lawyers may be more reluctant to accept due process cases. As we will see below, even when parents (and their child) prevail at due process, they often attain limited relief. Thus, lawyers and parents may have a negative view of the possible benefits of pursuing due process. Alternatively, the state may be doing a good job of attaining satisfactory resolutions through mediation or facilitated IEP meetings. It is striking, however, that the success rate for parents who use the complaint procedure seems to be higher than the success rate for parents who use the complaint process. If those results become well known, parents could increasingly seek to use the complaint process rather than due process hearings.

\section{B. Decisions}

A review of the eleven opinions issued in 2013 can provide a sense of how difficult it is for parents to use the due process system to attain effective relief. Although these cases are supposed to be decided within several months of the parent filing for due process, that time frame is virtually never met. ${ }^{123}$ In addition, when parents (and their child) do prevail, the relief is often quite limited. Because one opinion was issued based on an appeal of a case decided in 2013, these eleven opinions involve ten separate cases.

\section{Wild Wild West}

When interviewing lawyers who practice in the special education area, one lawyer described a due process hearing as the "wild wild west." The description can be seen in reference to some of these decisions. The most egregious is SE 2662-2012. ${ }^{124}$ The parent filed the due process complaint on

123 See STATE BD. EDUC. OHIO, supra note 13, \& 3301-51-05(K)(15) (requiring a decision 45 days after the expiration of a 30-day voluntary resolution period).

124 Green Local Sch. Dist., SE 2662-2012, rev'd in part, SLR 2662-2012. 
February 24, 2012 on behalf of her child. After various discovery skirmishes, the hearing officer informed the Department of Education on May 18, 2912 that he would need seven days, eight hours per day to conduct the hearing rather than the maximum fifty hours provided under state regulations. ${ }^{125}$ The hearing was then conducted over seven intermittent days in June 2012. An extension was granted to the school district, over the objection of the parent, and post-hearing briefs were filed in September 2012.126 The parties then agreed to extend the amount of time the hearing officer would have to issue his decision by twenty-eight days. When that date was close to expiring, the hearing officer granted himself another extension until December 19, 2012. ${ }^{127}$ On December 4, 2012, the hearing officer scheduled an additional day of hearing on December 27, 2012.128 It does not appear that either party requested that additional day of hearing. After further extensions and supplemental briefing, a 220-page decision was rendered on February 4, 2013.

As one might expect with a 220-page decision, the opinion contains numerous typos and sentences that are hard to follow. ${ }^{129}$ The opinion is so long because it contains extensive quotations from the transcript. The decision reads like a transcript rather than a summary of the facts. ${ }^{130}$ Citations to judicial decisions do not follow Bluebook format, so important information like court and date are sometimes missing. ${ }^{131}$ The recitation of the facts follows no apparent organization. Possibly, the facts are simply

\footnotetext{
$125 \mathrm{Id}$. at 8 .

$126 \mathrm{Id}$. at 9.

127 Id. at 9.

128 Id. at 9.
}

129 The typos and grammatical errors are scattered throughout the opinion. See, e.g., $i d$. at 171 ("parents" instead of "parents"); id. at 172 ("parents" instead of "parents"). The format for citations is informal and inconsistent. The opinion uses an "@" symbol instead of writing out "at" and provides incomplete citations so it is hard to know what each cite is referring to. For example, the opinion says Spielberg@250, instead of Spielberg, 853 F.2d at 250 . Id. at 175.

${ }^{130}$ For example, Dr. Melamed's evaluation is quoted extensively. Id. at 19, 21, 22, $23,24,26,27,28,29,30$. Those views could have been summarized succinctly. That type of recitation of the facts was used for all expert witnesses. In addition, lengthy question and answers are provided. See, e.g., id. at 110-11. There is no reason to provide the lengthy quotations from the transcript. Instead, he could have drawn a simple conclusion from the evidence.

131 For example, the citation to the Spielberg opinion fails to state that that decision is from the Fourth Circuit in 1988. Id. at 175. The failure to state the date is an important omission because Spielberg was decided before the IDEA was extensively amended in 2004. 
recited in the order that the testimony was offered. ${ }^{132}$ The statement of facts is repetitive for no apparent reason. ${ }^{133}$ The hearing officer also makes an egregious legal error. He applies a seclusion and restraint policy that had been adopted by the state of Ohio but had not yet gone into effect. ${ }^{134}$ The state level review officer found it to be inappropriate for the hearing officer to initiate the production of evidence. ${ }^{135}$ Finally, the state level review officer found that it was inappropriate for the hearing officer to refer to the 2013 policy, which was not even yet in effect, to reach his conclusions about seclusion and restraint.

This 220-page decision was not the only excessively long decision. The same hearing officer, Ronald Alexander, issued a 179-page opinion in another case. ${ }^{136}$ And, as in the previous case, the decision was quite delayed. The due process complaint was filed on June 1,2012 and a decision was not rendered until August 14, 2013. Finally, the same hearing officer rendered a 127-page opinion in another case. ${ }^{137}$ This case was resolved a bit more quickly. A complaint was filed on March 11, 2013 and a decision was rendered on November 7, 2013. This final case, however, involved a "stay put" matter that was initially supposed to be resolved on an expedited basis. ${ }^{138}$

Delayed decisions were not limited to decisions rendered by Ronald Alexander. Matthew Rohrbacher was the hearing officer in SE 2703-2012, in which the complaint was filed on May 7, 2012 but no decision was rendered until February 2013.139 This case only required a two-day hearing yet it took seven months for that hearing to be held after the complaint was filed.

132 For example, the opinion describes the student's diagnosis and assessment at the University of Pittsburgh in 2011 and describes the 2009 evaluation team report. Id at 40 , 68. It is confusing to read the facts out of chronological order.

133 For example, the hearing officer states that the student was credible in his belief that he was locked in the Chill Room and could not get out. Id. at 60, 193.

134 Id. at 187-89. See OHIO DeP'T OF EduC., POLICY ON POSITIVE BeHAVIOR INTERVENTIONS AND SUPPORT, AND RESTRAINT AND SECLUSION (2013), available at http://education.ohio.gov/getattachment/Topics/Other-Resources/School-Safety/BuildingBetter-Learning-Environments/Policy-Positive-Behavior-Interventions-and-

Support/Ohio-Department-of-Education-Policy-on-Positive-BehaviorInterventions.pdf.aspx.

135 Green Local Sch. Dist., SE 2662-2012 at 41.

136 Strongsville City Sch., SE 2715-2012.

137 Maple Heights Sch., SE 2803-2013.

138 See id. at 121.

139 Toledo Pub. Sch., SE 2703-2012. 


\section{SPECIAL EDUCATION COMPLAINT RESOLUTION}

The length of the due process decisions is not the only problematic factor. The decisions are often sloppily written and posted. Names of some, but not all, schools also seem to be deleted through the use of white out. ${ }^{140}$ This legibility problem could have been avoided by using generic references like "school" or "witness" or "teacher." There is also random green highlighter scattered in the decision. ${ }^{141}$ Further, SE 2814-2013 is difficult to read because the posted decision contains green highlighter as well as white redactions. ${ }^{142}$ The state's website also is not accessible to individuals with visual impairments, as required by the Americans with Disabilities Act. ${ }^{143}$

It is even difficult to use the website for research purposes because dates and headers are not always correct. SLR 2712-2012 is listed on the state's website as having been decided in 2012 but it was decided in 2013.144 Further, it is listed as "SE 2712-2012" which is the format for a first-level hearing officer decision. ${ }^{145}$ This case is actually decided by a second-level state level review officer and should be titled "SLR 2712-2012." Similarly, SLR 2702-2012 is listed on the state's website as having been decided in 2012 when it was decided in 2013. ${ }^{146}$ It is also listed as "SE 2702-2012" on the opinion itself, ${ }^{147}$ when it should have been titled "SLR 2702-2012" because it is also a state level review opinion.

The sloppiness used in writing and posting the decisions leaves the impression that the hearing officer process is very unprofessional in Ohio. Review of decisions for grammatical and spelling errors, as well as readability and consistency, would help improve the appearance of professionalism.

140 See, e.g., Maple Heights Sch., SE 2803-2013 at 18.

141 See, e.g., id. at 20.

142 See, e.g., Youngstown City Sch. Dist., SE 2814-2013 at 1.

143 Americans with Disabilities Act, 42 U.S.C. $\S 12132$ (2006) (requiring public entities not to deny the benefits of programs to qualified individuals with disabilities). For a discussion of the application of this rule to governmental websites, see U.S. Department of Justice, Civil Rights Division, Disability Rights Section, ADA, http://www.ada.gov /websites2.htm (last visited March 13, 2014).

144 See Due Process Decisions, supra note 113.

145 Id.

146 Id.

147 Cleveland Metro Sch. Dist., SLR 2702-2012-at 1. 


\section{Limited Relief}

Although students attained some relief in a majority of the cases, that relief was often quite limited, especially when compensatory relief was appropriate. In SE 2662-2012, the parents presented strong evidence that their son had not been receiving an appropriate education. ${ }^{148}$ The student had Prader-Willi Syndrome which results in an inability to feel satiated after eating, as well as an IQ in the extremely low range. ${ }^{149}$ The student's food security issues were so profound that his mother had to call the police to get assistance when he started to pull a knife on her. He was admitted to the Children's Institute in Pittsburgh. ${ }^{150}$ An expert from the Institute stated that the student "requires a lifetime residential placement." 151 He also stated that the only program in the country that met student's needs was the Latham Center in Cape Cod. ${ }^{152}$ Nonetheless, the IEP had no interventions that sought to respond to the profound food security issues. ${ }^{153}$ The student often slept for one-half to three hours at school in a room that the student testified was locked and was frequently subject to restraint. ${ }^{154}$ The parents introduced two videos of a staff member using restraints on the student. 155

In response to the entirely inadequate education being offered to their son through the public school, the parents chose to send their son to the Latham Center, as recommended by their expert. The hearing officer agreed that the parents should be reimbursed for the expense of sending their son to the Latham Center. ${ }^{156}$ But, remarkably, he awarded no compensatory education for the years in which the student was found not to have been provided an appropriate education, finding that the parents "provided no evidence that would enable the IHO to determine an amount or type of compensatory education that would place the Student in the position he would have occupied but for the School's denial of FAPE."157 This conclusion was very odd in light of the hundreds of pages of documentation of the student's lack of meaningful educational progress, and actual

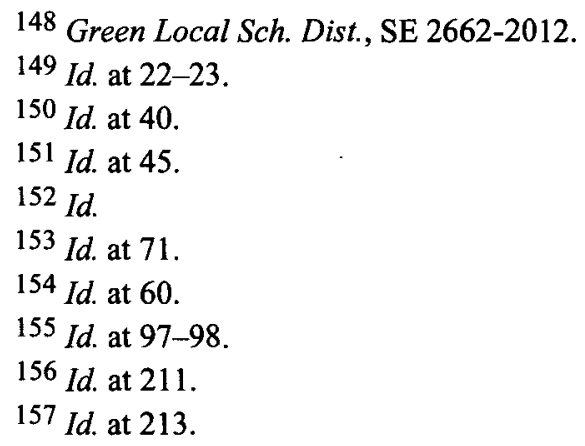


regression, along with consistent evidence that the school district had no employees qualified to teach the student. Rather than reduce the parent's requested compensatory education, he ordered no compensatory education at all. It is hard to see how that determination is consistent with his decision, as a hearing officer, to render a decision that is fair and equitable. The determination of the amount of compensatory education is a subjective determination. Given the voluminous record, it is hard to imagine that the parent's attorney offered "no" evidence in support of their request for an additional three years of compensatory education at the Latham Center.

Similarly, in SE 2784-2013, the hearing officer ordered one year of compensatory education, including extended school year services in his current placement. ${ }^{158}$ That award might seem appropriate, but it is quite limited in comparison to the facts. The student was subjected to repeated seclusion and restraint that clearly did enormous harm to the student. For example, when his father came to pick up the student one day, the student was "on his hands and knees, and had defecated, disrobed, and smeared feces all over himself and the room." 159

The hearing officer found that; in 2012-2013, the student:

[W] as removed from the classroom with such frequency and for such duration that he missed significant amounts of instructional time as well as opportunities to participate in classes, lunch and recess with non-disabled peers. Despite the ineffectiveness of the behavior and crisis plans implemented by Respondent as evidenced by continuously escalating aggressive and maladaptive behaviors, Respondent continued to utilize the plans on a daily basis for more than five months. Despite the clear ineffectiveness of the plans, they continued in use until Student's Mother refused to permit continued seclusion and restraint. 160

Amazingly, the hearing officer only found the student was denied an appropriate education for the 2012-2013 school year but not the 2011-2012 school year. The reason for this finding was that the hearing officer refused to use evidence from 2008 to find a regression in the student's skills because 2008 was outside the statute of limitations. ${ }^{161}$ Instead, he insisted on using

158 Mason School Dist., SE 2784-2013 at 18.

159 Id. at 11.

160 Id. at 20.

161 Id. at 17. 
data from February 2011 when his skills were so low that further regression was difficult to demonstrate.

The award of compensatory damages makes the case sound like the student just "missed" some instruction rather than the genuine facts-that student was exposed to repeated, harmful treatment that clearly caused significant emotional damage as evidenced by what the hearing officer calls "continuously escalating aggressive and maladaptive behaviors." 162

Both of these decisions misinterpret the case law on awards of compensatory damages. The leading case on awards of compensatory damages in Ohio is the Sixth Circuit decision in Board of Education $v$. L.M. ${ }^{163}$ That decision, in turn, relied extensively on the D.C. Circuit's decision in Reid v. District of Columbia, ${ }^{164}$ in which the D.C. Circuit reversed and remanded a compensatory education award by the district court.

Reid does an excellent job in explaining the basis for a compensatory education award, and contrasting that with the kind of relief that might be issued prospectively when an IEP is found to be invalid. The D.C. Circuit explained that "whereas ordinary IEPs need only provide 'some benefit,' compensatory awards must do more--they must compensate."165 The D.C. Circuit also had important language about the burden of proof in these matters. In the two cases, cited above, the hearing officer emphasized the burden on the parent to establish exactly how much compensatory education is needed. The D.C. Circuit placed the burden of proof quite differently. Once the parents had demonstrated that their child had been denied a free and appropriate public education, the D.C. Circuit found that the school district should be required "to offer proof that the placement compensated for prior FAPE denials in addition to providing some benefit going forward."166 Further, the D.C. Circuit concluded that the parents could prevail in overturning the hearing officer award "simply by pointing to the award's evident arbitrariness." 167 In the above two examples, especially the first one, it should be easy to argue, on appeal, that the hearing officer's decision was "arbitrary" in that he awarded absolutely no compensatory award, thereby not possibly compensating the child for the lost education.

162 Id. at 20.

163 Bd. of Educ. of Fayette Cnty., Ky. v. L.M., 478 F.3d 307 (6th Cir. 2007) (that decision is cited in Mason Sch. Dist., SE 2784-2013 at 22, and is cited in Green Local Sch. Dist., SE 2662-2012 at 212).

164 Reid ex rel. Reid v. Dist. of Columbia, 401 F.3d 516 (D.C. Cir. 2005).

$165 \mathrm{Id}$. at 525 .

166 Id.

167 Id. 
In the above two cases, the hearing officers also cited the passage from Reid where the court observed that a one-for-one standard in awarding compensatory education is not the correct rule, due to the individualized nature of decisions under the IDEA. ${ }^{168}$ But that observation is made out of context, not recognizing that the D.C. Circuit meant to allow for a situation in which even more than a one-to-one award is made. The court explicitly said: "Others may need extended programs, perhaps even exceeding hourfor-hour replacement of time spent without FAPE."169 In the particular case before the court, the D.C. Circuit recognized that possibility could apply because the student lost four and a half years of education, while denied FAPE, and "developed 'counterproductive' reading habits" during that period. ${ }^{170}$ In the second case, discussed above, the situation is parallel to Reid. The hearing officer found that the denial of FAPE caused "continuously escalating aggressive and maladaptive behaviors."171 Under such circumstances, it is easy to imagine that it will take more than a year of compensatory education to make up for that distinct harm.

\section{Systemic Problems with Due Process in Ohio}

These cases reflect some systemic problems with the due process system in Ohio. The first-tier hearing officers are independent contractors who are assigned to cases on a regional, rotating basis. They typically have another full-time job and schedule hearings during their vacation time or, sometimes, on weekends. Of the seven decisions rendered by first-level hearing officers, three were decided by Ronald Alexander, and one was decided by Matthew Rohrbacher, Todd Anthony Mazzola, Tobie Braverman, and Irene McMullen. In other words, only five of the fourteen individuals who are on the list of potential hearing officers actually heard a case in 2013. And, other than Ronald Alexander, they each heard only one case.

Ronald Alexander's website reflects he graduated from law school in 1971 and is engaged in a solo practice. ${ }^{172}$ Matthew Rohrbacher is an attorney

\footnotetext{
$168 I d$. at 524.

${ }^{169} \mathrm{Id}$.

$170 \mathrm{Id}$. at 525.

171 Mason Sch. Dist., SE 2748-2013 at 20.

172 RON ALEXANDER ESQ., http://www.ronalexanderesq.com (last visited Dec. 17,
} 2013). 
in a law firm in Toledo, Ohio; he graduated from law school in 1979.173 Todd Anthony Mazzola earned his law degree in 1993 and is a member of a law firm in Akron, Ohio. ${ }^{174}$ Tobie Braverman is an attorney in the Cincinnati area who serves as an attorney and labor arbitrator in private practice. She earned her law degree in 1979.175 Irene McMullen is an attorney in Chesterland, Ohio. She received her law degree in $1984 .{ }^{176}$ Other than Todd Mazzola, it appears that each of these individuals has been a hearing officer for many years. There appears to be little turn over in hearing officers.

One might expect that long-term experience with the due process system would be a positive factor for these hearing officers. Their long-standing status as a hearing officer, however, does not necessarily translate into a lot of experience working as a hearing officer. Only Ronald Alexander appears to have significant experience as a hearing officer. His lengthy opinions rendered after an extensive hearing-officer process does not seem consistent with the quick resolution of these matters that is promised by the IDEA.

Another problem reflected by the inconsistencies between these cases is that Ohio has no set of procedures that govern the resolution of these cases. Other states have operating procedures that govern the conduct of the hearings. ${ }^{177}$ CADRE has worked with various states to improve their state resolution system ${ }^{178}$ as reflected in its publication, Four Exemplary Dispute

173 Matthew Rohrbacher, ROHRBACHERS CRON MANAHAN TRIMBLE \& ZIMMERMAN Co., LPA, http://www.rcmtz.com/attomey-profile/matt-rohrbacher (last visited Dec. 17, 2013).

174 RODERICK LINTON BELFANCE LLP, http://www.rlbllp.com/todd-anthony-mazzola (last visited Dec. 17, 2013).

175 Tobie Braverman, OHIO DEP'T EDUC., https://education.ohio.gov/getattachment/ Topics/Special-Education/Mediation-Complaints-and-Due-Process/Impartial-hearingOfficers/South-Tobie-Braverman.pdf.aspx (last visited May 13, 2014).

176 Irene Hirata McMullen, OHIO DEP'T EDUC., http://education.ohio.gov/ getattachment/Topics/Special-Education/Mediation-Complaints-and-Due-Process

Impartial-hearing-Officers/Northeast-Irene-Hirata-McMullen.pdf.aspx (last visited Dec. 17, 2013).

177 For example, Massachusetts has hearing rules for special education appeals. See Hearing Rules for Special Education Appeals, MASS. DIV. ADMIN. L., BUREAU SPECIAL EDUC. APPEALS, http://www.mass.gov/anf/docs/dala/bsea/hearing-rules-2008.doc (last visited Mar. 13, 2014).

178 Bureau of Indian Educ. \& Albuquerque Serv. CTR., Resolution SESSion and Due Process Hearing Procedures in Speclal Education: Due Process HEARING OFFICER MANUAL (2007), available at http://www.directionservice.org/cadre/ exemplar/artifacts/ BIE-9\%20DPHO\%20manual.pdf. 
Resolution Systems in Special Education. ${ }^{179}$ In Ohio, attorneys report that the rules of evidence, for example, vary widely among the hearing officers, so it is hard to predict how a hearing will be conducted in advance. Both the school district and the lawyers for students and their parents complain about the length of the hearings and the inattention to the procedural safeguards that are supposed to guarantee speedy resolution to these cases.

One concern with respect to the conduct of hearings in Ohio is that school districts must compensate hearing officers on an hourly basis for their work. The direct transfer of funds from school districts to hearing officers gives the impression that the hearing officers are working for the school district rather than acting as neutral arbiters. Further, school districts do not like the fact that hearing officers have an incentive to prolong cases in order to make more money. A big issue is whether the decisions would be more efficient and more even-handed if hearing officers were not paid by the school district.

The question whether decisions would be more even-handed if hearing officers were not paid directly by the school district is hard to determine. I have also studied the results in due process decisions in California where the hearing officers are administrative law judges who work for the state on a full-time basis. My empirical evaluation of the results in California leads to the conclusion that students possibly fare even worse in California than they do in Ohio. When students do prevail in California, I have found that the remedies are especially stingy. ${ }^{180}$ When I spoke with lawyers in California about this problem, they hypothesized that the ALJ's perceive themselves as working for the state and thereby having an obligation to conserve state resources by awarding limited remedies. In Ohio, we also have this problem of "stinginess" already. Would it be exacerbated if the hearing officers were state employees?

\section{CONCLUSION}

Like all states, Ohio has two different mechanisms that parents can use to file a complaint about their child's education-they can file an administrative complaint or a due process complaint. In Ohio, the administrative process, at this time, seems more professional and more likely to attain some relief on

179 CENTER fOR APPROPRIATE DisPUTE RESOlution IN SPECIAL EdUCATION, http://www.directionservice.org/cadre/pdf/Combined\%20State\%20Profiles.pdf (last visited Jan. 4, 2014).

180 See Ruth Colker, California Year in Review: 2013 Special Education ALJ Decisions, 34 J. NAT'L ASS'N ADMIN. L. JUDICIARY (forthcoming 2014). 
behalf of the student than the hearing officer process. If Ohio would follow the path of other states, such as Pennsylvania, it might be able to improve the quality of decisionmaking in due process hearings by getting rid of a two-tier process and using professionals as decisionmakers. Lengthy delays before resolution is extremely problematic for students and is an urgent matter that needs correction in Ohio.

Nevertheless, I do not want to overstate the benefits of the administrative complaint process. One benefit that I noted above is that the investigator often examines issues that go beyond the initial complaint. That expanded role may further the interests of the student, but I spoke with one school superintendent who, not surprisingly, objected to this kind of "fishing expedition." By contrast, I also spoke with an advocate who said that his investigator refused to go beyond the narrow boundaries of the original complaint filed by the parent. As with due process hearings, the complaint investigation process would also benefit from clear, published standards so that school districts and parents know what to expect.

The complaint investigation process also presents an arguable conflict of interest. The complaint investigators are the same people who provide training to school districts. If the state has recently provided training to a school district, and then a complaint is filed, it would appear that the state investigator would be under pressure to conclude that the school district is in compliance. An out-of-compliance finding would implicitly question the value of the training offered by the state. If formal procedures were developed, they could address this kind of potential conflict of interest.

The results discussed in this article are limited to an investigation of the experience in the state of Ohio. This article reflects the first systematic review of results from the state complaint process. I have concluded that the investigative process often leads to efficient and fair relief for the student. And, in Ohio, the hearing officer system of resolving due process complaints often does not lead to efficient relief with time standards routinely not followed. It would be useful for researchers in other states to seek to replicate this analysis to see if similar results would be found in their states. Because of the variation in state practices, it is impossible to conclude from this one study if the complaint investigative process tends to produce better outcomes than the hearing officer process on a national level. 